CORRIGENDUM

\title{
The art of successful implementation of psychosocial interventions in residential dementia care: a systematic review of the literature based on the RE-AIM framework - CORRIGENDUM
}

Petra Boersma, Julia C.M. van Weert, Jeroen Lakerveld and Rose-Marie Dröes

http://dx.doi.org/10.1017/S1041610214001409. Published online by Cambridge University Press, 5 August 2014.

In the review 'the art of successful implementation of psychosocial interventions in residential dementia care: a systematic review of the literature based on the RE-AIM framework, the email for the corresponding author is incorrect. The correct email address is Petra.Boersma@Inholland.nl

\section{Reference}

Boersma, P., van Weert, J. C., Lakerveld, J., \& Dröes, R. M. The art of successful implementation of psychosocial interventions in residential dementia care: a systematic review of the literature based on the RE-AIM framework. International psychogeriatrics, published online 5 August 2014, http://dx.doi.org/10.1017/S1041610214001409 